\title{
Short communication: Efficacy of glycolic acid-based and iodine- based postmilking barrier teat disinfectants for prevention of new intramammary infections in dairy cattle
}

\author{
A. Lago, ${ }^{* 1}$ D. R. Bruno, $†$ M. Lopez-Benavides, $†$ and S. Leibowitz† \\ *DairyExperts Inc., Tulare, CA 93274 \\ †DeLaval Manufacturing, Kansas City, MO 64153
}

\section{ABSTRACT}

A positive-control, natural exposure noninferiority field study was conducted to test the efficacy of a novel glycolic acid-based postmilking barrier teat disinfectant compared with a commercial iodine-based postmilking barrier teat disinfectant (positive control). Cows from 2 pens from a California Central Valley dairy farm were dipped after milking either with the positive-control product $(\mathrm{PC})$ or the experimental product $(\mathrm{EX})$ over 12 wk. New intramammary infections (NIMI) were determined by biweekly sampling of all quarters of study cows and classified as a NIMI based on somatic cell count and milk bacteriological culture results. The mean quarter-level incidence risks during a 2 wk study period were $3.50 \%$ (EX) and $4.28 \%(\mathrm{PC})$. The majority of NIMI were caused by coagulase-negative staphylococci, followed by non-agalactiae streptococci. The study results indicated that EX was noninferior to PC, with a $17 \%$ relative efficacy (improvement) in reducing NIMI compared with the PC group. Also, quarter somatic cell count was not affected by the postmilking teat disinfectant used. Finally, the EX product was safe in terms of teat conditioning: teat condition scores were not different between study groups. The study concluded that the glycolic acid-based experimental post-dip barrier was noninferior to the control, and could be considered a safe and effective postmilking teat disinfectant.

Key words: mastitis, postmilking teat disinfectant, bacteria, barrier

\section{Short Communication}

Bovine mastitis continues to have significant effects in the dairy industry. In spite of major advances in the prevention and treatment of mastitis in dairy cows over the past several decades, it remains the leading

Received November 19, 2015.

Accepted May 9, 2016.

${ }^{1}$ Corresponding author: alfonso.lago@dairyexperts.com cause of decreased milk production, lower milk quality, animal loss, and ultimately reduced profit for the dairy producer (Hogan et al., 1984; Ruegg, 2012). Topical disinfection of teats before and after milking, with products proven effective at reducing new IMI (NIMI), has been used with benefit for decades. Disinfection of the teat skin after milking helps reduce the spread of mastitis pathogens by preventing them from entering and colonizing the mammary gland (Neave et al., 1969; Vijaya Kumar et al., 2012). Various products exist for pre- and postmilking teat disinfection, and several publications have documented the effectiveness of these products in preventing IMI in dairy cows (Oliver et al., 2001; Hillerton et al., 2007; Ceballos-Marquez et al., 2013). The National Mastitis Council (www.nmconline. org) has also published a bibliography of peer-reviewed research on the efficacy of commercially available teat disinfectants (National Mastitis Council, 2014). Postmilking teat disinfectants must have a persistent and effective killing action, and they must leave teats in good condition. Preservation of healthy teat skin is essential for maintaining its natural defense against infection (Hogan et al., 1990; Mein et al., 2001), because sore, dry, cracked teats may harbor mastitis-causing pathogens (Blowey and Edmondson, 2010). Barriertype teat disinfectants have been developed to extend the germicidal properties of the disinfectant after the cow leaves the milking parlor. These products contain components that can provide a protective film and seal the teat from mastitis-causing bacteria (Nickerson and Boddie, 1995).

Split-herd study designs have some advantages over split-udder designs. Split-herd designs are more practical when enrolling large number of animals and are less likely to underestimate the effect size of prevention or treatment strategies implemented at the cow level due to interdependence between quarters (Berry et al., 2003). Recently, Ceballos-Marquez et al. (2013) was able to demonstrate the noninferiority of an experimental product relative to a positive control using a split herd with pen-level treatment allocation. The National Mastitis Council has protocols available for testing teat 
disinfectants under natural conditions (Nickerson et al. 2004). Adjustments to existing protocols have been proposed to test the noninferiority of an experimental product compared with a control product, based on adequate statistical approaches and reasonable logistical modifications (Ceballos-Marquez et al., 2013).

The goal of the present study was to evaluate the effectiveness and safety of a newly developed glycolic acid-based postmilking barrier teat disinfectant OceanBlu Barrier (EX; GlyTec and 10\% emollients; DeLaval Manufacturing, Kansas City, MO). Glycolic acid is naturally present in milk (NICNAS, 2000) and has limited germicidal activity, but GlyTec (DeLaval Manufacturing) is a proprietary blend of glycolic acid (3\%) and other ingredients that overcomes glycolic acid's limitations related to germicidal efficacy. The primary objective of this study was to demonstrate the noninferiority of EX compared with an existing iodine-based positive-control postmilking barrier teat disinfectant, Blockade (PC; $1 \%$ iodine and 10\% emollients; WestAgro Chemical Inc., Des Plaines, IL) in preventing NIMI that occur under natural circumstances on a commercial dairy farm. The secondary objective of this study was to assess the teat skin safety of the 2 products by monitoring teat condition.

Sample size calculation ( $\alpha=0.05$ and $80 \%$ power $)$ estimated that 125 to 150 animals (500-600 quarters) per group would be necessary to adequately power the study. The required sample size was calculated using a confidence interval approach, considering where the confidence intervals for the test product effects lay with respect to the margin of noninferiority $(\boldsymbol{\Delta})$ and a null effect (all products are equal). A prestated $\Delta$ of $30 \%$ was specified as a difference in proportion of NIMI. In general, a product is considered efficacious if its efficacy is at least $40 \%$ for negative-control trials and $70 \%$ for positive-control trials (Schukken et al., 2013). Therefore, the efficacy of a test product cannot be less than $30 \%$ compared with a positive control. The estimate for test product efficacy relative to a positive control was defined as Efficacy (test product ${ }_{1}$ vs. positive control) $=1-\exp (\beta 1)$, where $\beta 1$ is the log of the incidence risk of NIMI between the test product and the positive control. To obtain the actual ratio, the value of $\beta 1$ is exponentiated.

This 12-wk, split-herd, positive-control noninferiority field trial was conducted in a commercial dairy farm in the Central Valley of California in the United States. Cows were housed in open-lot pens bedded with manure dried out by stirring and sun exposure, and milked twice a day in a double-21 herringbone parlor. At the dairy, cows in all lactations were moved to high-yield milking pens without following any cow-dependent criteria at about 1 mo after calving; cows left their pens when they were moved to a dry-off pen or were culled. In the current study, cows from 2 high-yield milking pens were used: cows from one pen were assigned to EX and cows from the other were assigned to PC. Feeding and management practices were the same in both pens. The same premilking teat disinfectant, Opti Blue (1.6\% linear dodecyl benzene sulfonic acid and $2 \%$ glycerin; DeLaval) was used in both pens. We used stratified randomization between first-lactation and mature cows at the pen level to ensure that the same number of cows were enrolled in both study groups. Late-lactation cows were not enrolled in the study, so that all cows in both groups were less than 260 DIM. Finally, cows in both groups were balanced by status of infection before the beginning of the study period.

Once the trial started, pre- and postmilking products were applied using a color-coded nonreturn dip cup that matched the numbered, colored leg bands on the cows, identifying the cow and the study group assigned. Two milk samples, one for SCC determination and another for aerobic culture, were collected every 2 wk from each quarter of all cows from wk -2 to 12. Each teat was prepared using a fastidious sampling technique that included the following steps: premilking disinfection, forestripping, wiping dry after 30 to $45 \mathrm{~s}$ of contact time, scrubbing the teat end with an alcohol scrub, discarding 3 or 4 squirts of foremilk, and finally collecting 2 milk samples. Milk samples for SCC analysis were collected into $60 \mathrm{~mL}$ vials containing bronopol and analyzed the next day at the DHIA (Tulare, CA). Milk samples for aerobic culture were collected into sterile $13 \mathrm{~mL}$ flip-top milk sampling vials and placed in a cooler with ice to be transported on the same day to DairyExperts Laboratory (Tulare, CA) and stored in a freezer $\left(-20^{\circ} \mathrm{C}\right)$. For the first sampling (wk -2$)$ samples from all quarters of all cows underwent SCC determination and culture for bacteriology. In subsequent samplings (wk 0 to 12 ) SCC was determined on all samples and thresholds were used to determine which samples were eligible for culture (Schepers et al., 1997; Lopez-Benavides et al., 2012). Only milk samples from first-lactation heifers with SCC $\geq 100,000$ cells/ $\mathrm{mL}$ and from cows in second or greater lactation with SCC $\geq 200,000$ cells $/ \mathrm{mL}$ were submitted for culture. Although the application of products on-farm could not be blinded, all laboratory outcome assessments for SCC and milk bacteriology were done blindly without knowledge of treatment assignment.

We determined SCC using a Somatocount 500 (Bentley Instruments Inc., Chaska, MN), according to the document on enumeration of SCC in milk FIL.IDF 148 A:95 norm (IDF, 1995). When SCC results were available, qualifying milk samples were cultured using aerobic microbiological techniques. Briefly, individual 
quarter milk samples were thawed at room temperature. While the sample was still cold, $0.01 \mathrm{~mL}$ of milk was plated onto MacConkey, TKT, and Factor agar using sterile calibrated loops. Factor agar, similar to KLMB agar (Beatty et al., 1985), selects for gram-positive organisms and inhibits the growth of gram-negative bacteria with antibiotics. Inoculated plates were incubated at $37^{\circ} \mathrm{C}$. After incubation for $24 \mathrm{~h}$, all plates were observed for microbial growth. Plates with growth were recorded and species identification started. All plates were placed in the incubator for an additional $24 \mathrm{~h}$ and reevaluated for microbial growth. Colonies on MacConkey agar plates were presumptively identified based on colony morphology. Colony color was used as a means of determining if the organism on the plate was a lactosefermenting organism. Isolates were also gram-stained to assist in organism identification. Organism identity was confirmed using oxidase, triple sugar iron (TSI), motility indole ornithine (MIO), and Simmons citrate biochemical tests. Colonies on Factor agar suspected of being Staphylococcus spp. based on morphology were confirmed based on catalase reaction and microscopic morphology. Organisms suspected of being Staphylococcus aureus were confirmed using the tube coagulase reaction. Organisms that were catalase-positive and coagulase-negative were classified as Staphylococcus spp. Finally, esculin reaction was determined on TKT medium, which is selective for Streptococcus spp., before organism confirmation using Christie, Atkins, MunchPeterson (CAMP) and bile esculin medium.

Subclinical mastitis was determined based on SCC levels above the defined threshold and IMI definition from the bacteriological culture results. An IMI was defined as being present when a single colony (from a 0.01-mL milk sample) was isolated from any bacterial species with the exception of CNS. This definition resulted in the best sensitivity and a specificity estimate of $>94 \%$ (Dohoo et al. 2011). For CNS, the IMI definition was the presence of 2 or more colonies from a $0.01-\mathrm{mL}$ milk sample, which resulted in an acceptable specificity of $95 \%$. Samples containing more than 2 bacterial species were considered contaminated and were not informative of IMI status. The following organisms were considered for IMI: Staph. aureus, Streptococcus agalactiae, Staphylococcus spp., Streptococcus spp., Streptococcus uberis, Streptococcus dysgalactiae, Corynebacterium spp., Escherichia coli, and other coliforms. An IMI or the absence of IMI was identified in any quarter from the sample collected at wk -2 using the above definition. Throughout the remainder of the study, IMI were quarters that were sampled for bacteriological culture because they showed an SCC value above the defined threshold or came from clinical mastitis cases. Clinical mastitis was identified by the milkers at the parlor by the appearance of abnormal milk (wateriness, flakes, or clots), and a milk sample was collected aseptically for bacteriological culture at DairyExperts Laboratory.

The initial bacteriological status of each quarter was established at the beginning of the trial. Once an IMI was identified in a quarter, the infection was considered a NIMI only if the microorganism isolated was different from those isolated previously in the same quarter. Culture results from clinical mastitis cases were also considered for NIMI.

Teat health was monitored using a subjective scoring scale of 1 to 5 (Mein et al., 2001) for teat barrel skin, teat end roughness, and teat end thickness. Scoring was performed at wk $0,4,8$, and 12 . Teat evaluation was carried out by the same operators at each visit and was performed after the milking unit had been removed and before the postmilking teat disinfectant was applied.

We used GLIMMIX PROC in SAS (version 9.3; SAS Institute, Cary, NC) to analyze the quarter-level incidence risk of NIMI during a 2-wk study period (binary response variable), as a function of treatment group and other covariates using logistic multivariable regression with generalized estimating equations to account for the clustering of quarters within cows. Time was included as a fixed effect, and the interaction with treatment as categorical variables and cow was included as a random effect. Covariates evaluated included the quarter location (front vs. hind), cow lactation, DIM, and trial 2-wk period.

We used the MIXED procedure in SAS to analyze SCC and teat-condition data. The analysis was carried out on natural $\log$ scale for SCC (lnSCC) to provide normal distribution of the data. The $\mathrm{lnSCC}$ was modeled as a function of explanatory variables using linear multivariable regression. A multilevel general linear mixed model was constructed with $\operatorname{lnSCC}$ as a continuous, normally distributed response variable. The model was specified with random variation allowed in 2 hierarchical levels (repeated measure of $\operatorname{lnSCC}$ within quarters and variation among quarters within a cow) by specifying a correlation structure among the repeated measurements of the same quarters [repeated test/ subject $=$ quarters type $=$ ar (1) r rcorr] and including a random statement. A first-order autoregressive correlation structure was chosen based on goodness-of-fit measures. These models were also used for the analysis of teat barrel skin condition, teat end roughness, and teat end thickness.

The study was performed as anticipated and no problems were encountered. Average daily temperatures during the study period (July-October) ranged from $20^{\circ} \mathrm{C}$ to $32^{\circ} \mathrm{C}$. Milking equipment was checked twice, at 


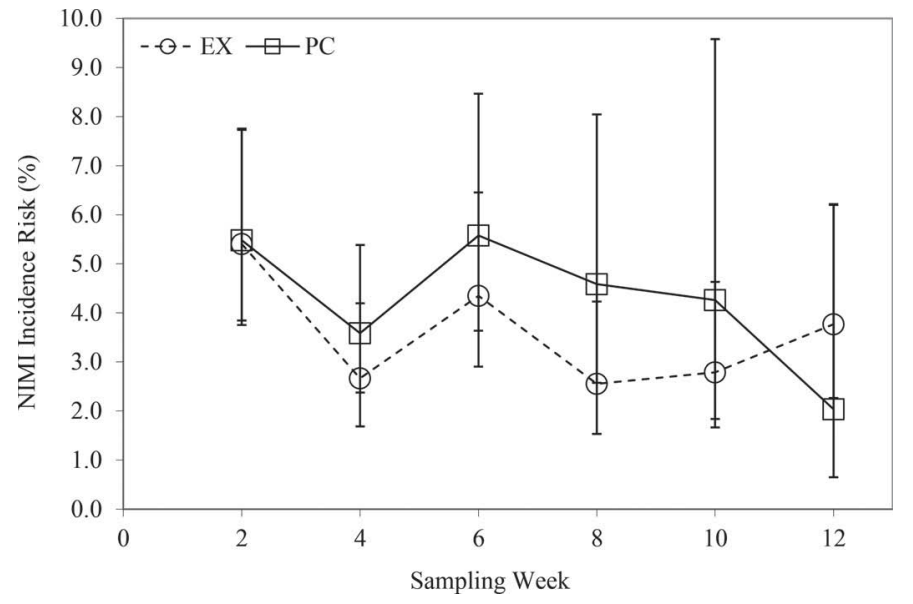

Figure 1. Model-based LSM $( \pm \mathrm{SE})$ of the incidence risk $(\%)$ of having a new IMI (NIMI) in all at-risk quarters of cows in the experimental (EX) and positive control (PC) groups.

the beginning and midpoint of the study period. Issues encountered in the first system evaluation were corrected before the next evaluation.

A total of 299 cows with 1,185 quarters, 153 cows in EX and 146 in PC, were enrolled in the study (wk -2), of which 281 cows with 1,102 quarters started the study 2 wk later (wk 0). The reason for the 18-cow difference between wk -2 and wk 0 was that extra cows were cultured at wk -2 to be able to balance study groups by IMI status. The average DIM at enrollment was 160 and was not different between groups. We observed no differences between groups in the prevalence of IMI in samples collected the day before the beginning of the trial (wk 0) or in incidence of NIMI during the $2 \mathrm{wk}$ before (from wk -2 to wk 0). Finally, lnSCC, teat skin condition, and teat end roughness and thickness scores at baseline (wk 0) were not different between groups.

A total of 4,547 quarter milk samples were collected during the study sampling dates (wk 2 to 12). Samples were cultured from 1,189 quarters based on SCC thresholds. Of the cultured samples, 46.5\% (EX) and $52.8 \%$ (PC) were culture-positive. The most frequently isolated pathogen in both groups was CNS (84.5\%), followed by non-agalactiae streptococci $(10.4 \%)$, coliforms (4.2\%), and Corynebacterium spp. (0.9\%).

The quarter-level incidence risk of NIMI for the 2 -wk study periods is shown in Figure 1. The mean model-based quarter-level incidence risk of NIMI during a 2 -wk study period was $3.50 \%(\mathrm{SE}=0.48)$ for $\mathrm{EX}$ and $4.28 \%(\mathrm{SE}=0.59)$ for PC. Most subclinical NIMI were due to CNS (79.9\% for EX and $84.9 \%$ for PC), followed by non-agalactiae streptococci $(14.2 \%$ for EX and $10.0 \%$ for PC), coliforms $(3.9 \%$ for EX and $3.4 \%$ for PC), and Corynebacterium spp. (2.0\% for EX and $1.7 \%$ for PC). We obtained 51 samples from clinical mastitis cases, in which coliforms $(45.0 \%$ for EX and $40.0 \%$ for PC), Staphylococcus spp. (30.0\% for EX and $26.7 \%$ for PC), and non-agalactiae streptococci (20.0\% for EX and $26.7 \%$ for PC) were the most common bacteria isolated. Corynebacterium spp. represented $5.0 \%$ for $\mathrm{EX}$ and $6.6 \%$ for $\mathrm{PC}$ of the pathogens isolated from clinical mastitis cases. Bacteria were not isolated in 33.3 and $28.5 \%$ of the clinical mastitis cases for EX and $\mathrm{PC}$, respectively.

The relative efficacy (improvement) in reducing NIMI of EX versus PC based on the regression model estimate was $17 \%(P=0.15$; odds ratio: $0.82,95 \% \mathrm{CI}$ : 0.63-1.07; Table 1). We concluded that EX was noninferior to PC because the upper limit of the confidence

Table 1. Final multivariable logistic regression model describing the effect of treatment with an experimental postmilking teat disinfectant on odds of acquiring a new IMI from wk 2 to 12

\begin{tabular}{|c|c|c|c|c|c|c|}
\hline \multirow[b]{2}{*}{ Variable } & \multirow[b]{2}{*}{ Estimate } & \multirow[b]{2}{*}{$\mathrm{SE}$} & \multirow{2}{*}{$\begin{array}{l}\text { Odds } \\
\text { ratio }\end{array}$} & \multicolumn{2}{|c|}{$95 \% \mathrm{CI}^{1}$} & \multirow[b]{2}{*}{$P$-value } \\
\hline & & & & LCL & UCL & \\
\hline Intercept & -3.41 & 0.33 & & & & \\
\hline Disinfectant & & & & & & 0.15 \\
\hline Experimental & -0.19 & 0.13 & 0.82 & 0.63 & 1.07 & \\
\hline Positive control & Referent & & & & & \\
\hline Time (wk) & & & & & & $<0.01$ \\
\hline 2 & 0.44 & 0.25 & 1.55 & 0.94 & 2.55 & \\
\hline 4 & -0.13 & 0.26 & 0.87 & 0.51 & 1.46 & \\
\hline 6 & 0.33 & 0.26 & 1.40 & 0.83 & 2.33 & \\
\hline 8 & -0.09 & 0.28 & 0.91 & 0.51 & 1.60 & \\
\hline 10 & -0.06 & 0.30 & 0.90 & 0.50 & 1.64 & \\
\hline 12 & Referent & & & & & \\
\hline Lactation & & & & & & $<0.01$ \\
\hline 1 & -1.10 & 0.24 & 0.33 & 0.20 & 0.53 & \\
\hline $2+$ & Referent & & & & & \\
\hline DIM & 0.002 & $<0.001$ & 1.003 & 1.001 & 1.004 & $<0.01$ \\
\hline
\end{tabular}




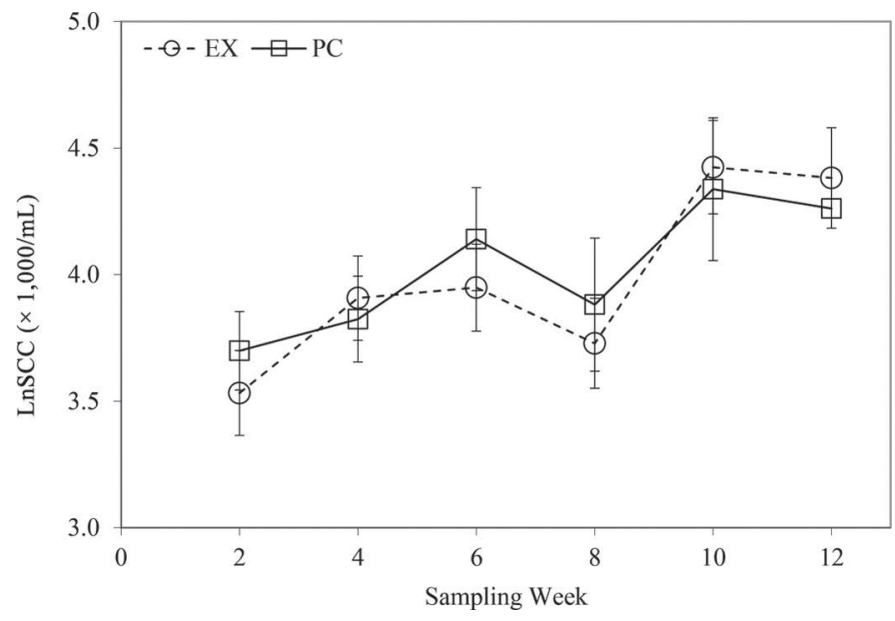

Figure 2. Model-based LSM of natural log scale for SCC $( \pm \mathrm{SE})$ of cows in the experimental (EX) and positive control (PC) groups for the 12 -wk study period.

interval was $10 \%$, less than the $\Delta$ of $30 \%$. In the regression model, the effect of time was significant, but the interaction of time with treatment on the incidence risk of having a NIMI was not significant in the generalized linear mixed model. Cow lactation group ( 1 vs. $2+)$ and DIM at enrollment were significant and stayed in the model. Other covariates, such as quarter location (front vs. hind) and presence of a NIMI during the pretrial period, were not significant and were dropped from the model.

Previous studies have reported the adequate efficacy of iodine disinfectants (Pankey et al., 1987; Oliver et al., 1993). Additionally, the positive control product used in this study has been shown to prevent more IMI than other iodine-based postmilking disinfectants

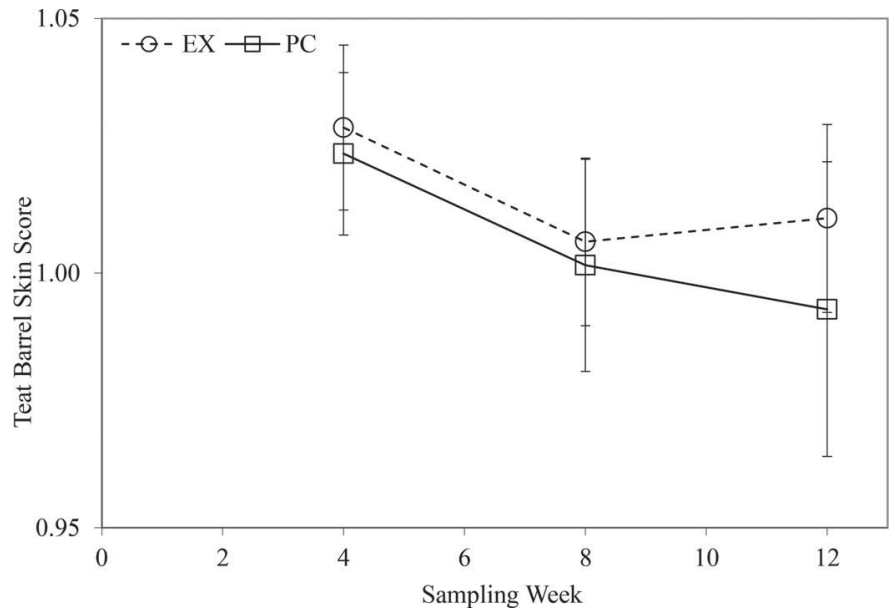

Figure 3. Model-based LSM of teat barrel skin scores $( \pm \mathrm{SE})$ of cows in the experimental (EX) and positive control (PC) groups for the 12-wk study period.
(Foret et al., 2006). The present study found that the glycolic acid-based experimental product resulted in numerically fewer NIMI than the iodine-based control. Consequently, it is expected that both EX and PC would reduce the NIMI risk relative to a negative control.

We expected that diagnostic error would be small because of the series testing diagnostic process (i.e., high SCC and culture-positive). Series testing results in increased specificity and decreased sensitivity (Smith and Slenning, 2000; Dohoo et al., 2009). Sample size estimations used in this study accounted for the estimated loss in sensitivity due to series testing. Also, the small difference in incidence risk of NIMI between the 2 treatments in the present study should result in small bias in efficacy estimates due to diagnostic error (Morant et al., 1988).

From the total of 4,547 samples collected, SCC analysis was performed at each sampling date. The overall back-transformed lnSCC means were 61,559 cells $/ \mathrm{mL}$ (EX) and 64,071 cells/mL (PC). The overall proportion of quarters with high SCC (based on the defined threshold) was $24.00 \%$ for EX and $25.40 \%$ for PC. The product used for postmilking teat disinfection had no significant effect on overall $\operatorname{lnSCC}(P=0.69)$ (model not shown). Figure 2 shows LSM of $\operatorname{lnSCC}$ by study group.

A total of 1,724 quarter evaluations were performed at wk 4, 8, and 12 of the study. For EX and PC, respectively, average teat barrel skin scores were 1.00 and 1.00 (Figure 3, $P=0.43$ ), teat end roughness scores were 1.52 and 1.55 (Figure $4, P=0.43$ ), and teat end thickness scores were 1.45 and 1.60 (Figure $5, P=0.79$ ) (models not shown). We concluded that no differences existed between EX and PC in terms of teat health and teat condition.

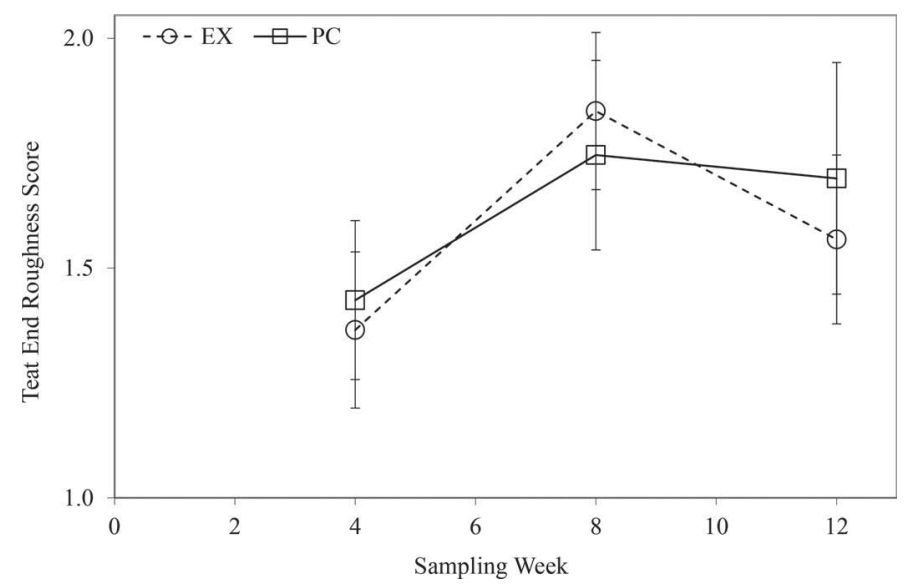

Figure 4. Model-based LSM of teat end roughness scores $( \pm \mathrm{SE})$ of cows in the experimental (EX) and positive control (PC) groups for the 12 -wk study period. 


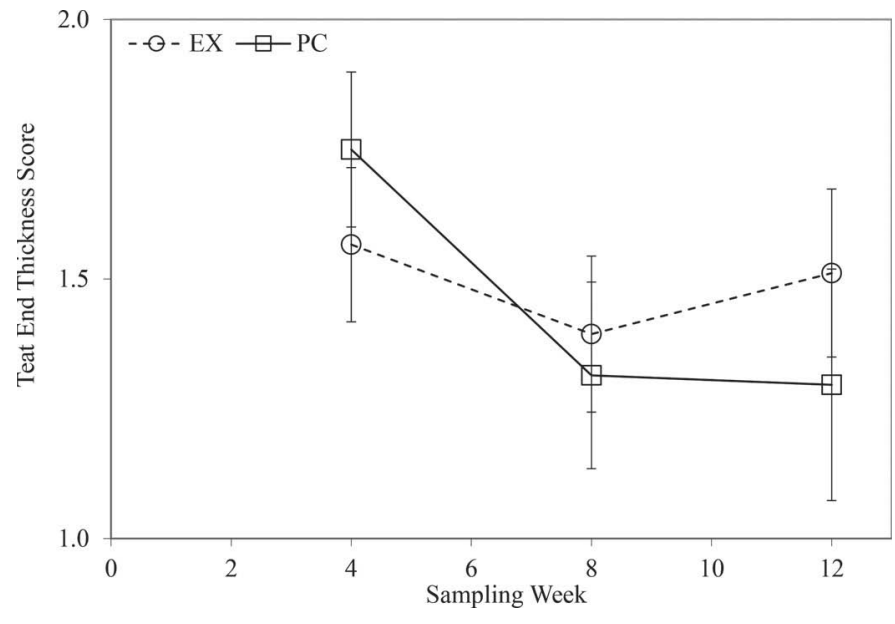

Figure 5. Model-based LSM of teat end thickness scores $( \pm \mathrm{SE})$ of cows in the experimental (EX) and positive control (PC) groups for the 12 -wk study period.

The results of this trial indicated that the glycolic acid-based product OceanBlu Barrier (DeLaval) was noninferior to the iodine-based control product Blockade (DeLaval) for the prevention of naturally occurring NIMI. In addition, we found no difference between the products concerning SCC. Finally, teat skin health parameters were not different between the study groups, leading us to conclude that OceanBlu Barrier can be considered safe in terms of teat conditioning and efficient in preventing NIMI.

\section{REFERENCES}

Beatty, B., R. Farnsworth, A. Lund, R. Lyon, and G. Ward. 1985. Medium to culture and differentiate coagulase-positive and -negative staphylococci from bovine milk. J. Food Prot. 48:1019-1021.

Berry, E. A.. W. T. Johnston, and J. E. Hillerton. 2003. Prophylactic effects of two selective dry cow strategies accounting for interdependence of quarter. J. Dairy Sci. 86:3912-3919.

Blowey, R. W., and P. Edmondson. 2010. Mastitis in Dairy Herds. 2nd ed. CABI International, Wallingford, UK.

Ceballos-Marquez, A., T. Hemling, B. J. Rauch, M. Lopez-Benavides, and Y. H. Schukken. 2013. Noninferiority trial on the efficacy of premilking teat disinfectant against naturally occuring new intramammary infections using a novel 2-step diagnostic process. J. Dairy Sci. 96:8081-8092.

Dohoo, I. R., W. Martin, and H. Stryhn. 2009. Veterinary Epidemiologic Research. 2nd ed. VER Inc., Charlottetown, PEI, Canada.

Dohoo, I. R., J. Smith, S. Andersen, D. F. Kelton, and S. Godden. 2011. Diagnosing intramammary infections: Evaluation of definitions based on a single milk sample. J. Dairy Sci. 94:250-261.

Foret, C., H. Aguero, and P. Janowicz. 2006. Efficacy of two barrier iodine teat dips under natural exposure conditions. J. Dairy Sci. 89:2279-2285.

Hillerton, J. E., J. Cooper, and J. Morelli. 2007. Preventing bovine mastitis by a postmilking teat disinfectant containing acidified sodium chlorite. J. Dairy Sci. 90:1201-1208.

Hogan, J. S., D. M. Galton, R. J. Harmon, S. C. Nickerson, S. P. Oliver, and J. W. Pankey. 1990. Protocols for evaluating efficacy of post-milking teat dips. J. Dairy Sci. 73:2580-2585.
Hogan, J. S., R. J. Harmon, B. E. Langlois, R. W. Hemken, and W. L. Crist. 1984. Efficacy of an iodine backflush for preventing new intramammary infections. J. Dairy Sci. 67:1850-1859.

IDF (International Dairy Federation). 1995. Enumeration of Somatic Cells. FIL-IDF Standard no. 148A. IDF, Brussels, Belgium.

Lopez-Benavides, M., A. Ceballos-Marquez, B. J. Rauch, T. Hemling, and Y. H. Schukken. 2012. Use of SCC thresholds to decide microbiological culture of milk samples in field trials. Pages 197-198 in Natl. Mastitis Counc. Ann. Mtg. Proc., St. Pete Beach, FL. Natl. Mastitis Counc., Inc., Madison, WI.

Mein, G. A., F. Neijenhuis, W. F. Morgan, D. J. Reinemann, J. E. Hillerton, J. R. Baines, I. Ohnstad, M. D. Rasmussen, L. Timms, J. S. Britt, R. Farnsworth, N. Cook, and T. Hemling. 2001. Evaluation of bovine teat condition in commercial dairy herds: 1 . Noninfectious factors. Pages 347-351 in 2nd International Symposium on Mastitis and Milk Quality. Natl. Mastitis Counc., Inc., Madison, WI.

Morant, S. V., F. H. Dodd, and R. P. Natzke. 1988. Consequences of diagnostic errors in mastitis therapy trials. J. Dairy Res. 55:315329.

NICNAS (National Industrial Chemicals Notification and Assessment Scheme). 2000. Glycolic acid. Priority existing chemical report no. 12, Commonwealth of Australia. Section 7.6. NICNAS, Department of Health, Australian Government, Sydney, NSW, Australia.

Neave, F. K., F. H. Dodd, R. G. Kingwell, and D. R. Westgarth. 1969 Control of mastitis in the dairy herd by hygiene and management. J. Dairy Sci. 52:696-707.

Nickerson, S. C., and R. L. Boddie. 1995. Efficacy of barrier-type postmilking teat germicides against intramammary infection. J. Dairy Sci. 78:2496-2501.

Nickerson, S. C., A. Saxon, L. K. Fox, T. Hemling, J. S. Hogan, J. Morelli, S. P. Oliver, W. E. Owens, M. Pawlak, and L. G. Petersson. 2004. Recommended protocols for evaluating efficacy of postmilking teat germicides. Pages 379-399 in Natl. Mastitis Counc. Ann. Mtg. Proc., Charlotte, NC. Natl. Mastitis Counc. Inc., Madison, WI.

National Mastitis Council. 2014. Summary of peer-reviewed publications on efficacy of pre-milking and post-milking teat disinfectants published since 1980. Pages 245-258 in Natl. Mastitis Counc. Mtg. Proc., Orlando, FL. Natl. Mastitis Counc., Inc., Madison, WI.

Oliver, S. P., B. E. Gillespie, M. J. Lewis, S. J. Ivey, R. A. Almeida, D. A. Luther, D. L. Johnson, K. C. Lamar, H. D. Moorehead, and H. H. Dowlen. 2001. Efficacy of a new premilking teat disinfectant containing a phenolic combination for the prevention of mastitis. J. Dairy Sci. 84:1545-1549.

Oliver, S. P., M. J. Lewis, T. L. Ingle, B. E. Gillespie, K. R. Matthews, and H. H. Dowlen. 1993. Premilking teat disinfection for the prevention of environmental pathogen intramammary infections. J. Food Prot. 56:852-855.

Pankey, J. W., E. E. Wildman, P. A. Drechsler, and J. S. Hogan. 1987. Field trial evaluation of premilking teat disinfection. J. Dairy Sci. 70:867-872.

Ruegg, P. 2012. New perspectives in udder health management. Vet. Clin. Food Anim. Pract. 28:149-163.

Schepers, A. J., T. J. G. M. Lam, Y. H. Schukken, J. B. M. Wilmink, and W. J. A. Hanekamp. 1997. Estimation of variance components for somatic cell counts to determine thresholds for uninfected quarters. J. Dairy Sci. 80:1833-1840.

Schukken, Y. H., B. J. Rauch, and J. Morelli. 2013. Defining standardized protocols for determining the efficacy of a postmilking teat disinfectant following experimental exposure of teats to mastitis pathogens. J. Dairy Sci. 96:2694-2704.

Smith, R. D., and B. D. Slenning. 2000. Decision analysis: Dealing with uncertainty in diagnostic testing. Prev. Vet. Med. 45:139-162.

Vijaya Kumar, A., L. Venkateswara Rao, M. Kishan Kumar, B. Srinu, and T. Madhava Rao. 2012. Efficacy of udder disinfectants on reduction of bacterial load and certain pathogens of public health significance. J. Microbiol. Biotech. Res. 2:147-151. 